\title{
UPAYA PENINGKATAN AKTIVITAS DAN HASIL BELAJAR BIOLOGI MELALUI PENGGUNAAN METODE DISKUSI PADA SISWA KELAS VII MTs. MUHAMMADIYAH MARGOTOTO TAHUN PELAJARAN 2011/2012
}

\author{
MUQOSIM \\ ANAK AGUNG OKA \\ Pendidikan Biologi FKIP Universitas Muhammadiyah Metro \\ E-mail: qocim_wae@yahoo.com
}

\begin{abstract}
The purpose of this study were to increase the biological activity and learning outcomes through the discussion method. In the theory, discussion method is a method in the learning process so that students dare to issue his opinion, daring to ask and answer questions. The analysis of data showed an increase in activity and student learning outcomes. The research was conducted at grade VII MTs. Muhammadiyah Margototo academic year 2011/2012. Expression increased the activity of 10.29\%, the activity of your friends pay attention when presenting the results of their discussion to increase $24.02 \%$, the activity increased $11.27 \%$ to ask questions, answer questions activity increased $16.67 \%$ and complete the task group activities increased $19.52 \%$. On learning outcomes also increased with evidence of students increased to $24 \%$ complete.
\end{abstract}

Kata Kunci: Diskusi, Aktivitas Belajar, Hasil Belajar.

Belajar merupakan suatu proses usaha yang dilakukan seseorang untuk memperoleh suatu perubahan tingkah laku serta pengetahuan yang baik secara keseluruhan sebagai hasil pengalamannya sendiri dalam interaksi dengan lingkungan. Sedangkan prestasi belajar merupakan taraf keberhasilan murid atau penguasaan materi dalam mempelajari materi pelajaran di sekolah dan dinyatakan dalam bentuk skor atau nilai yang diperoleh dari hasil tes dalam materi pelajaran tertentu. Prestasi yang baik akan sulit dicapai bila guru tidak memiliki kompetensi dalam pembelajaran. Sebagai tolak ukur keberhasilan dari sebuah pembelajaran, biasa dilihat dari ketuntasan hasil belajar siswa pada Tabel 1. Nilai aktivitas Belajar Siswa setiap pokok bahasan dengan diberikannya soal evaluasi sebagai bahan pengukur kemampuan siswa terhadap penguasaan materi yang telah diserap selama pembelajaran berlangsung.

Berdasarkan hasil prasurvei pada saat pembelajaran, siswa ketika diberi kesempatan untuk menjawab pertanyaan dan bertanya lebih banyak diam serta siswa tidak berani mengeluarkan pendapatnya bila diberi kesempatan untuk mengeluarkan pendapat dan bila diberi tugas untuk mengerjakan soal banyak siswa yang tidak mengerjakan. Pada kondisi seperti ini menyebabkan hasil belajar biologi belum mencapai maksimal. 


\begin{tabular}{|l|l|c|c|}
\hline No & \multicolumn{1}{|c|}{ Indikator } & Frekuensi & Presentase \\
\hline 1 & Mengeluarkan pendapat & 4 & $11,76 \%$ \\
\hline 2 & Mengerjakan soal & 20 & $58,82 \%$ \\
\hline 3 & Mencatat dan merangkum & 21 & $61,76 \%$ \\
\hline 4 & Bertanya kepada guru & 3 & $8,88 \%$ \\
\hline 5 & Menjawab pertanyaan & 2 & $5,88 \%$ \\
\hline
\end{tabular}

Tabel 2. Nilai aktivitas Belajar Siswa

\begin{tabular}{|c|c|l|c|c|}
\hline No. & Nilai & Kategori & Jumlah siswa & Persentase \\
\hline 1 & $\geq 65$ & Tuntas & 22 & $65 \%$ \\
\hline 2 & $<65$ & Tidak Tuntas & 12 & $35 \%$ \\
\hline \multicolumn{2}{|c|}{ Jumlah } & 34 & $100 \%$ \\
\hline
\end{tabular}

Dasil hasil pra survei yang peneliti lakukan pada tanggal 1 Desember 2011 di MTs. Muhammadiyah Margototo didapatkan nilai aktivitas belajar biologi kelas VII dapat dilihat pada Tabel 1. Selanjutnya adalah data pra survai mengenai hasil belajar biologi siswa kelas VII MTs. Muhammadiyah Margototo yang disajikan pada Tabel 2.

Dari Tabel 1 dapat dilihat bahwa dari 34 siswa ada 4 siswa atau sebesar $11,76 \%$ yang mengeluarkan pendapat, ada 20 siswa atau sebesar 58,82\% yang mengerjakan soal, kemudian 21 siswa atau sebesar $61,76 \%$ yang mencatat dan merangkum, dan 3 siswa atau $8,88 \%$ yang bertanya kepada guru, dan 2 atau sebesar 5,88\% yang menjawab pertanyaan.

Berdasarkan data pada Tabel 2, menunjukkan bahwa hasil belajar masih rendah atau masuk kategori tidak tuntas yaitu yang memperoleh nilai < 65 terdapat $35 \%$. Sedangkan hasil belajar yang diharapkan adalah ketuntasan belajar siswa sesuai dengan Kriteria Ketuntasan Minimal (KKM) yaitu 65.

Dari hasil data pra survei yang dilakukan pada tanggal 1 Desember 2011 ditemukan fakta aktifitas siswa yang tidak tuntas dalam pembelajaran yaitu : 1) siswa tidak berperan aktif dalam proses belajar, 2) siswa lebih banyak diam saat guru mengajukan pertanyaan, 3) sulitnya memahami pelajaran dan kurangnya siswa mengajukan pendapat sehingga siswa terlihat kurang aktif dalam belajar. Masalah tersebut perlu diupayakan pemecahannya, salah satunya dengan metode pembelajaran yang tepat untuk dapat meningkatkan aktivitas siswa dalam belajar sekaligus dapat meningkatkan hasil belajar siswa. Dalam hal ini peneliti memilih metode pembelajaran yang dianggap tepat untuk meningkatkan aktivitas belajar dan hasil belajar yaitu dengan metode diskusi, karena dengan metode ini siswa diharapkan mampu memahami materi, sehingga akan meningkatkan hasil belajar. Selain itu dengan menerapkan metode diskusi akan terjadi aktivitas siswa berupa tukar menukar informasi, pendapat, dan unsur-unsur pengalaman secara teratur dengan maksud untuk mendapat pengertian bersama yang lebih jelas dan lebih teliti tentang sesuatu atau untuk mempersiapkan dan menampung keputusan bersama.

Selain itu dengan adanya metode diskusi, siswa diharapkan dapat memperoleh pengetahuan serta pengalaman dalam belajar karena dengan metode ini siswa dapat secara 
langsung menyelesaikan dan memecahkan masalah yang ada di dalam pelajaran biologi tersebut. Menurut Syah (2011:216) "prestasi belajar ideal meliputi segenap ranah psikologis yang berubah sebagai akibat pengalaman dan proses belajar siswa”. Hal ini bermaksud prestasi belajar akan didapatkan bila siswa tersebut melakukan kegiatan yang dikatakan belajar. Sedangkan menurut Yasa (2008) prestasi belajar dapat diartikan "sebagai hasil yang dicapai oleh individu setelah mengalami suatu proses belajar dalam jangka waktu tertentu”. Selain itu juga prestasi selalu dihubungkan dengan aktivitas tertentu, seperti dikemukakan oleh Gagne yang dikutip Abdullah (2008) “dalam setiap proses akan selalu terdapat hasil nyata yang dapat diukur dan dinyatakan sebagai hasil belajar (Achievement) seseorang".

Sehingga dapat diberikan kesimpulan hasil belajar merupakan sebuah pencapaian akan penguasaan materi yang telah dipelajari dan dilakukan pembelajarannya baik dalam ruang kelas atau di luar kelas, atau dengan kata lain hasil belajar dapat dilihat melalui hasil evaluasi dari setiap pokok bahasan sebagai alat ukur dari keberhasilan pembelajaran yang telah dilakukan.

Untuk mencapai proses pembelajaran dan hasil belajar dipengaruhi beberapa faktor diantaranya penggunaan metode. Diskusi merupakan komunikasi seseorang berbicara satu dengan yang lain, saling berbagi gagasan dan pendapat. Menurut Mulyasa (2009:116) "diskusi dapat diartikan sebagai percakapan responsif yang dijalin oleh pertanyaan-pertanyaan problematis yang diarahkan untuk memperoleh pemecahan masalah”. Hal ini selaras dengan pendapat Djamarah dan Zain
(2010:87) metode diskusi adalah "cara penyajian pelajaran dimana siswasiswa dihadapkan pada suatu masalah yang bisa berupa pernyataan atau pertanyaan yang bersifat problematis untuk dibahas dan dipecahkan bersama”. Jadi dalam pembelajaran yang dilakukan dengan metode diskusi akan membuat siswa terbiasa menghadapi dan memecahkan suatu permasalahan.

Menurut Sofa (2008) bahwa yang dikatakan dengan metode diskusi pembelajaran adalah: 1) Siswa belajar bermusyawarah, 2) Siswa mendapat kesempatan untuk menguji tingkat pengetahuan masing-masing, 3) Belajar menghargai pendapat orang lain, dan 4) Mengembangkan cara berpikir dan sikap ilmiah. Selain itu juga menurut Suryobroto (dalam Trianto, 2010:123) bahwa diskusi dapat digunakan oleh guru dengan pertimbangan : 1) Memanfaatkan berbagai kemampuan yang ada (dimiliki) oleh siswa, 2) Memberikan kesempatan kepada para siswa untuk menyalurkan kemampuannya masing-masing, 3) Memperoleh umpan balik dari siswa tentang apakah tujuan yang telah dirumuskan telah tercapai, 4) Membantu para siswa belajar berpikir teoritis dan praktis lewat berbagai mata pelajaran dan kegiatan sekolah, 5) Membantu para siswa belajar menilai kemampuan dan peranan diri sendiri maupun teman-temannya (orang lain), 6) Membantu para siswa menyadari dan mampu merumuskan berbagai masalah yang dilihat baik dari pengalaman sendiri maupun dari pelajaran sekolah, 7) Mengembangkan motivasi untuk belajar lebih lanjut.

Menurut Gibbs (dalam Mulyasa, 2009:164) kreativitas dapat dikembangkan dengan memberi kepercayaan, komunikasi yang bebas, pengarahan diri, dan pengawasan yang 
tidak terlalu ketat. Dengan pemberian perlakuan tersebut aktivitas siswa akan memberikan pengaruh terhadap peningkatan cara belajar serta aktivitas yang dilakukan. Peningkatan aktivitas ini terjadi karena dalam setiap akhir pembelajaran yang telah dilakukan guru memberikan sedikit motivasi dalam menutup pembelajaran, serta menguatkan rasa ingin belajar yang telah ada dalam diri siswa. Serta penguatan siswa dala pembelajaran akan memberikan kebebasan siswa dalam berekspresi dengan gaya belajar dan memecahkan permasalahan yang dihadapinya.

Berdasarkan beberapa hal di atas, maka melalui metode diskusi akan memberikan peningkatan aktivitas dan hasil belajar siswa. Hal ini diakibatkan dalam diskusi siswa diberikan peran melakukan penggalian informasi yang selengkap mungkin dalam menghadapi permasalahan yang diberikan sebagai memahami kemampuan dan mengembangkan ranah kognitif siswa. Dengan membiasakan siswa melakukan berdiskusi maka akan memberikan sustu pemahaman dalam belajar kita tidak secara individual sehingga dengan belajar bersama dalam memecahkan permasalahan bersamasama siswa akan belajar yang lebih bermakna dan memberikan pengetahuan dan pemahaman yang lebih mendalam dari sebuah materi.

Berdasarkan latar belakang di atas, dapat dirumuskan masalah dalam penelitian ini yaitu : Apakah pembelajaran dengan metode diskusi dapat meningkatkan aktivitas dan hasil belajar pada siswa kelas VII MTs. Muhammadiyah Margototo TP 2011/20012 ?. Penelitian ini bertujuan untuk meningkatkan aktivitas dan hasil belajar pada siswa kelas VII MTs. Muhammadiyah Margototo TP 2011/20012. Sedangkan manfaat yang diharapkan dari penelitian ini yaitu : 1) Memberikan masukan bagi guru dan calon guru IPA dalam upaya untuk meningkatkan aktivitas, dan hasil belajar IPA terpadu; 2) Menjadikan pembelajaran yang menyenangkan bagi siswa, serta meningkatkan aktivitas belajar, dan hasil belajar IPA terpadu; 3) Hasil penelitian ini memberikan sumbangan yang bermanfaat bagi sekolah dalam mendukung perbaikan pembelajaran IPA terpadu khususnya.

\section{METODE}

Penelitian ini merupakan penelitian tindakan kelas yang dilaksanakan pada semester genap tahun pelajaran 2011/2012 pada siswa MTs. Muhammadiyah Margototo pada standar kompetensi memahami saling ketergantungan dalam ekositem, dengan kompetensi dasar : 1) Menentukan ekosistem dan saling hubungan antara komponen ekosistem, dan 2) Memprediksi pengaruh kepadatan populasi manusia terhadap lingkungan. Penelitian tindakan kelas ini dilaksanakan dalam 2 siklus yang meliputi tahap-tahap dalam penelitian yaitu : 1) perencanaan, 2) pelaksanaan tindakan, 3) observasi dan evaluasi tindakan, dan 4) refleksi dari perjalanan setiap pertemuan yang dilaksanakan selama pembelajaran. Pembelajaran dilaksanakan selama 3 kali pertemuan dengan alokasi waktu setiap pertemuan (2 x 40 menit) sedangkan penelitian dilaksanakan mulai tanggal 1 Juni sampai dengan 4 juli 2012. Penelitian dilaksanakan di MTs. Muhammadiyah Margototo Lampung-timur pada semester genap tahun pelajaran 2011/2012 dengan subjek penelitian siswa VII dengan jumlah siswa 34 siswa dengan tingkat kemampuan yang beragam. Sedangkan objek penelitian metode diskusi dalam meningkatkan aktivitas dan hasil belajar siswa. 
Dalam penelitian, peneliti melakukan tahap tahap penelitian dengan memngkaji materi yang akan dilakukan pembelajarannya selama penelitian, setelah itu mempersiapkan segala perangkat pembelajaran yang akan digunakan selama penelitian seperti silabus, rencana pelaksanaan pembelajaran serta soal sebagai evaluasi pembelajaran.dalam tahap pelaksanaan peneliti melaksanaan pembelajaran dengan aplikasi metode diskusi dan mengamati aktivitas yang dilakukan siswa sebagai bahan kajian apakah siswa yang melakukan aktivitas belajar yang baik akan memberikan hasil belajar yang baik. Pada setiap akhir siklus diadakan tes evaluasi yang digunakan sebagai tolak ukur akan kemampuan dipahaminya materi oleh siswa dan diberikan. Pada tahap terakhir adalah refleksi dilakukan pada setiap akhir pertemuan dan akhir siklus dalam menkaji pembelajaran yang dilakukan.

\section{HASIL}

Analisis data observasi dalam penelitian tindakan kelas antara siklus I dan siklus II terus mengalami peningkatan. Hal ini didasarkan pada siklus I yaitu menjelaskan kegagalan pada evaluasi aktivitas siswa serta tindak lanjut agar siklus selanjutnya mengalami peningkatan. Dari tabel dapat diketahui bahwa semua jenis aktivitas dalam pembelajaran dengan menggunakan metode diskusi mengalami peningkatan dari siklus I ke siklus II yang peningkatannya itu bervariasi setiap jenis aktivitasnya. Peningkatan aktivitas siswa dari siklus I ke siklus II terlihat pada tabel 3.

Dari Tabel 3 dapat dijelaskan bahwa mengeluarkan pendapat dari 11,76 meningkat menjadi 22,05 dengan peningkatan 10,29, memperhatikan teman mempresentasikan hasil diskusi dari 62,74 meningkat menjadi 86,76 dengan peningkatan 24,02, mengajukan pertanyaan dari 10,78 meningkat menjadi 22,05 dengan peningkatan 11,27, enjawab pertanyaan dari 6,86 meningkat menjadi 23,53 dengan peningkatan 16,67, menyelesaikan tugas kelompok 74,50 meningkat menjadi 94,12 dengan peningkatan 19,52 .

Tabel 3. Peningkatan Aktivitas Belajar Siswa

\begin{tabular}{|l|l|c|c|c|}
\hline No & \multicolumn{1}{|c|}{ Jenis aktivitas } & $\begin{array}{c}\text { Rata-rata } \\
\text { siklus I (\%) }\end{array}$ & $\begin{array}{c}\text { Rata-rata } \\
\text { siklus II (\%) }\end{array}$ & $\begin{array}{c}\text { Peningkatan } \\
(\%)\end{array}$ \\
\hline 1 & Mengeluarkan pendapat & 11,76 & 22,05 & 10,29 \\
\hline 2 & $\begin{array}{l}\text { Memperhatikan teman } \\
\text { mempresentasikan hasil } \\
\text { diskusi }\end{array}$ & 62,74 & 86,76 & 24,02 \\
\hline 3 & Mengajukan pertanyaan & 10,78 & 22,05 & 11,27 \\
\hline 4 & Menjawab pertanyaan & 6,86 & 23,53 & 16,67 \\
\hline 5 & $\begin{array}{l}\text { Menyelesaikan tugas } \\
\text { kelompok }\end{array}$ & 74,50 & 94,12 & 19,52 \\
\hline$\quad$ Jumlah & $166,64 \%$ & $248,51 \%$ & $81,77 \%$ \\
\hline \multicolumn{2}{|c|}{ Rata-rata } & $33,33 \%$ & $49,70 \%$ & $16,35 \%$ \\
\hline
\end{tabular}

Tabel 4. Ketuntasan Hasil Belajar Siswa 


\begin{tabular}{|c|c|c|c|c|c|c|c|c|c|c|}
\hline \multirow{2}{*}{ No } & \multirow{2}{*}{ Kategori } & \multirow{2}{*}{ KKM } & \multicolumn{3}{|c|}{ Banyak siswa } & \multicolumn{3}{|c|}{ Persentase } & \multicolumn{2}{|c|}{$\begin{array}{c}\text { Pening katan } \\
\text { dari Pra PTK- } \\
\text { Siklus } 2\end{array}$} \\
\hline & & & $\begin{array}{l}\text { Pra } \\
\text { PTK }\end{array}$ & $\begin{array}{c}\text { Sik } \\
1\end{array}$ & $\begin{array}{c}\text { Sik } \\
2\end{array}$ & $\begin{array}{l}\text { Pra } \\
\text { PTK }\end{array}$ & Siklus 1 & Siklus 2 & $\begin{array}{l}\text { Banyak } \\
\text { siswa }\end{array}$ & (\%) \\
\hline 1 & Tuntas & $\geq 65$ & 22 & 25 & 30 & $64,70 \%$ & $73,52 \%$ & $88,23 \%$ & \multirow[b]{2}{*}{8} & \multirow{2}{*}{$\begin{array}{l}24 \\
\%\end{array}$} \\
\hline 2 & $\begin{array}{l}\text { Belum } \\
\text { tuntas }\end{array}$ & $<65$ & 12 & 9 & 4 & $35,29 \%$ & $26,47 \%$ & $11,76 \%$ & & \\
\hline & umlah & & 34 & 34 & 34 & $100 \%$ & $100 \%$ & $100 \%$ & & \\
\hline
\end{tabular}

Berdasarkan hasil evaluasi dengan tes sebahai tolak ukur pemahaman siswa terhadap pembelajaran yang telah dilakukan. Hasil belajar siswa pada praPTK siswa yang mengalami ketuntasan belajar dari 25 siswa dengan persentase $73,52 \%$ pada siklus I menjadi 30 siswa dengan persentase $88,23 \%$ pada siklus II dan siswa belum tuntas belajar dari 9 siswa dengan persentase $26,47 \%$ pada siklus I berkurang menjadai 4 siswa dengan persentase $11,76 \%$ pada siklus II. Untuk melihat peningkatan hasil belajar siswa secara signifikan data dapat di lihat dalam tabel berikut.

\section{PEMBAHASAN}

Pembelajaran dengan metode diskusi memberikan pembelajaran yang menyenangkan sebanding peningkatan aktivitas dan hasil belajar siswa, pernyataan tersebut dapat dilihat pada data tabel peningkatan aktivitas pembelajaran sebagai berikut:

1) Mengeluarkan pendapat pada siklus I dan siklus II untuk indikator mengeluarkan pendapat diperoleh hasil pada siklus I yaitu 11,76\% dan 22,05\% pada siklus II dengan peningkatan 10,29\%. Untuk indikator mengeluarkan pendapat, target yang diinginkan telah tercapai yaitu dengan adanya peningkatan jumlah aktivitas pada siklus I ke II. Peningkatan aktivitas ini terwujud dikarnakan setiap siswa diharuskan untuk mencoba mengeluarkan pendapatnya dari awal siklus I hingga akhir siklus II. 2) Memperhatikan teman mempresentasikan hasil diskusinya, pada siklus I dan siklus II untuk indikator memperhatikan teman saat mempresentasikan hasil diskusinya diperoleh hasil pada siklus I yaitu $62,74 \%$ dan pada siklus II yaitu 86,76\% dengan peningkatan 24,02\%. Untuk indikator memperhatikan teman saat mempresentasikan hasil diskusinya, target yang diinginkan telah tercapai yaitu dengan adanya peningkatan jumlah aktivitas pada siklus I ke II. Peningkatan aktivitas ini terwujud dikarnakan siswa menyadari bahwa memperhatikan teman saat mempresentasikan hasil diskusi sangat penting dalam pembelajaran secara berkelompok ataupun diskusi. Hasil penelitin ini mempertegas pernyataan Dierich (dalam hamalik 2005:172) ) bahwa jenis-jenis aktivitas itu terbagi menjadi: kegiatan visual, lisan (Oral), mendengarkan, memperhatikan, menggambar, memetrik, kegiatan mental dan emosional. 3) Mengajukan Pertanyaan Pada siklus I dan siklus II untuk indikator mengajukan pertanyaan diperoleh hasil pada siklus I yaitu 
$10,78 \%$ dan pada siklus II yaitu $22,05 \%$ dengan peningkatan $11,27 \%$. Hal ini dikarenakan siswa termotivasi untuk mendapat tambahan nilai yang diberikan oleh guru dan siswa menyadari bahwa dengan bertanya dapat menambah pengetahuannya. Berdasarkan penelitian diketahui bahwa metode diskusi dapat meningkatkan aktivitas mengajukan pertanyaan karena dalam bertanya dapat meningkatkan pengetahuan siswa dalam hal mengajukan pertanyaan sehingga siswa menjadi lebih aktif dalam bertanya. Hasil penelitian tersebut mempertegas pernyataan Sardiman (2009:24) bahwa "Bagi siswa bertanya menunjukkan perhatian terhadap materi yang dipelajari dan ada upaya untuk menemukan jawaban sebagai bentuk pengetahuan”. 4) Menjawab Pertanyaan, pada siklus I dan siklus II untuk indikator menjawab pertanyaan diperoleh hasil pada siklus I yaitu $6,86 \%$ dan $23,53 \%$ pada siklus II dengan peningkatan 16,67\%. Untuk indikator menjawab pertanyaan, target yang diinginkan telah tercapai yaitu dengan adanya peningkatan jumlah aktivitas pada siklus II. Dilihat dari siklus I dan siklus II kemampuan siswa dalam menjawab pertnyaan mengalami peningkatan. Kemampuan seperti ini disebabkan kerena siswa telah mampu mengoptimalkan dan mengembangkan kemampuan yang telah dimiliki mereka sehingga menghasilkan hasil yang lebih baik dari sebelumnya. Menyelesaikan tugas kelompok, pada siklus I dan siklus II untuk indikator menyelesaikan tugas kelompok diperoleh hasil pada siklus I yaitu $74,50 \%$ dan $94,12 \%$ pada siklus II dengan peningkatan 19,52\%. Untuk indikator mengeluarkan pendapat, target yang diinginkan telah tercapai yaitu dengan adanya peningkatan jumlah aktivitas pada siklus I ke siklus
II. Seperti yang diungkapkan oleh Winkel (1983:48) yaitu "aktivitas belajar atau kegiatan belajar yang menghasilkan suatu perubahan yang khas yaitu prestasi belajar yang dicapai”.

Menurut Djamarah dan Zain (2010:105) "keberhasilan belajar mengajar tercapai apabila suatu belajar dinyatakan berhasil apabila mencapai tujuan dari perencanaan/ target”. Sesuai dengan pendapat tersebut ketercapaian ketuntasan hasil belajar yang ditentukan oleh sekolah mengindikasikan pembelajaran yang dilaksanakan dengan aplikasi metode diskusi dan tugas memberikan dampak pembelajaran yang menyenangkan dan bermakna sehingga pemehaman siswa terhadap materi dikuasai dengan baik.. Selain itu terdapat faktor motivasi yang dapat berpengaruh terhadap keberhasilan dari hasil belajar siswa dan faktor tersebut dapat berasal dari dalam diri siswa yakni rasa keingintahuan yang besar dalam proses pembelajaran. Dalam hal motivasi menurut Gleitman dan Reber (dalam Syah, 2011:153) "motivasi merupakan pemasok daya (Energizer) untuk bertingkah laku terarah”. Motivasi itu dapat berasal dari dalam diri siswa (intrinsik) dan keadaan yang mendorong namun berasal dari luar individu (ekstrinsik). Motivasi yang diberikan oleh guru dalam pembelajaran akan meningkatkan rasa ingin belajar siswa dan meningkatkan aktivitas belajar siswa serta frekuensi belajar atau frekuensi aktivitas belajar siswa. Dengan penguatan motivasi ekstrinsik peneliti bisa meningkatkan target dari ketercapaian seberapa besar hasil yang diinginkan oleh siswa terhadap hasil belajar yang akan didapatkan. Dengan penguatan motivasi yang berfungsi sebagai dorongan kepada siswa, maka siswa 
akan termotivasi dengan berbagai halhal yang mampu membuat siswa belajar dengan maksimal mungkin dengan mencapai nilai tertinggi yang diharapkannya.

\section{KESIMPULAN DAN SARAN}

\section{Kesimpulan}

1. Berdasarkan hasil penelitian yang dilakukan, dapat disimpulkan bahwa: Metode diskusi dapat meningkatkan aktivitas belajar siswa kelsa VII MTs. Muhammadiyah Margototo yaitu peningkatan tertinggi pada aktivitas memperhatikan teman saat mempresentasikan hasil diskusinya sebesar 24,02\% dan peningkatan terendah pada aktivitas mengeluarkan pendapat sebesar 10,29\%.

2. Metode diskusi dapat meningkatkan hasil belajar siswa kelas VII MTs. Muhammadiyah Margototo. Peningkatan hasil belajar siswa yang tuntas belajar dari 25 siswa dengan presentase $73,52 \%$ pada siklus I meningkat menjadi 30 siswa dengan presentase 88,23\% pada siklus II.

\section{Saran}

Berdasarkan kesimpulan yang didapatkan dari hasil penelitian, maka peneliti memberikan saran dan pertimbangan pada guru atau pembaca yaitu: 1) Dalam pembelajaran aplikasikanlah metode diskusi untuk meningkatkan aktivitas dan hasil belajar siswa dan dapat menjadi alternatif metode pembelajaran yang digunakan dalam pembelajaran IPA terpadu, 2) Dengan metode diskusi akan menumbuhkan rasa tanggung jawab serta mengembangkan pengetahuan dengan pencarian pengetahuan secara mandiri pengalaman belajar akan menyenangkan bagi siswa. Dengan pembelajaran yang menyenangkan maka aktivitas belajar siswa akan meningkat serta proses belajar yang bermakna bagi siswa. Sedangkan peningkatan aktivitas belajar akan berpengaruh atas minat belajar dengan aktivitas belajar yang meningkat maka hasil belajar akan meningkat akibat sebuah proses pembelajaran. 3) Metode diskusi merupakan pembelajaran yang menekankan pada aktivitas belajar siswa, namun dalam belajar ada aktivitas yang dapat mangganggu pembelajaran. Maka sebagai saran peneliti, penguasaan kelas harus dikuasai oleh peneliti selanjutnya mengembangkan fungsi guru dalam pembelajaran sesuai tugas yang dimiliki oleh guru. Karena dalam peningkatan pembelajaran di sekolah seorang guru menjadi peran utama dalam keberhasilan sebuah tujuan pendidikan.

\section{DAFTAR RUJUKAN}

Abdullah, Abu Muhammad Ibnu. 2008. "Prestasi Belajar". (Online). (http://Spesialis-

Torch.Com/Content/View/120/2 9/). diakses 5 Mei 2011.

Djamarah, Syaiful Bahri dan Zain, Aswan. 2010. Strategi Belajar Mengajar. Jakarta : Rineka Cipta.

Hamalik, Oemar. 2005. Metodologi dan Kesulitan-Kesulitan Belajar. Bandung: Tarsito. 
Mulyasa, E. 2009. Menjadi Guru Profesional. Bandung: PT. Remaja Rosdakarya.

Sardiman. 2009. Interaksi Dan Motivasi Belajar. Jakarta: Rajawali

Syah, Muhibbin. 2011. Psikologi Belajar. Jakarta: Rajawali Press.

Silberman, Melvin L. 2004. Active Learning 101 Cara Belajar Siswa Aktif. Bandung: Nuansa dan Nusa Media.

Sofa. 2008. "Metode Diskusi dalam Pembelajaran”. (Online). (http://massofa.wordpress.com/ 2008/07/13/metode-diskusidalam- pembelajaran/). diakses 25 Oktober 2011.

Trianto. 2010. Mendesain Model Pembelajaran InovatifProgresif. Jakarta: Kencana.

Winkel, W. S. 1983. Psikologi Pendidikan Dan Evaluasi Belajar. Jakarta:

Gramedia

Yasa, Doantara. 2008. ”Aktivitas dan Prestasi Belajar". (Online). (http://ipotes.wordpress.com/20 08/05/24/prestasi-belajar/). diakses 5 mei 2011. 